\title{
Effect of Tuber Crop Wastes/Byproducts on Nutritional and Microbial Composition of Vermicomposts and Duration of the Vermicomposting Process
}

\author{
M. Nedunchezhiyan, ${ }^{1}$ S. K. Jata, ${ }^{1}$ G. Byju, ${ }^{2}$ and S. S. Veena ${ }^{2}$ \\ ${ }^{1}$ Regional Centre of Central Tuber Crops Research Institute, Bhubaneswar, Odisha 751 019, India \\ ${ }^{2}$ Central Tuber Crops Research Institute, Thiruvananthapuram, Kerala 751 019, India
}

Correspondence should be addressed to M. Nedunchezhiyan, mnedun@gmail.com

Received 15 August 2011; Revised 17 October 2011; Accepted 31 October 2011

Academic Editor: Curtis C. Daehler

Copyright (C) 2011 M. Nedunchezhiyan et al. This is an open access article distributed under the Creative Commons Attribution License, which permits unrestricted use, distribution, and reproduction in any medium, provided the original work is properly cited.

\begin{abstract}
A pot culture experiment on vermicomposting of cassava and sweet potato wastes/byproducts was conducted for MarchMay (season I) and June-August (season II) during 2010 at the Regional Centre of Central Tuber Crops Research Institute, Bhubaneswar, Orissa. The study revealed that the vermicompost prepared from biomass and byproducts of tuber crops had fairly higher levels of nitrogen (1.12-2.23\%), phosphorus (0.26-0.88\%), and potassium (0.33-1.29\%) compared to initial status. The vermicompost prepared from sweet potato dry leaves had the highest nitrogen $(2.23 \%$ and $2.03 \%)$, phosphorus $(0.88 \%$ and $0.69 \%$ ), and potassium ( $1.29 \%$ and $0.84 \%$ ) content during both the years of study. Cassava thippi (tuber residue) required $40-43$ days for the complete conversion into vermicompost, whereas all other biomass and byproducts needed more time (43-65 days). The rate of increase of earthworm weight and population was higher in vermicompost made from cassava and sweet potato thippi. Microbial counts indicated that populations of bacteria and fungi were higher in season I, whereas actinomycetes were higher in season II. The study indicated that all the biomass and byproducts of tuber crops can be effectively converted into high-value vermicompost.
\end{abstract}

\section{Introduction}

Vermicomposting has been reported to be a viable, costeffective, and rapid technique for the efficient utilization of crop residues and byproducts and organic wastes [1$3]$. It provides two useful products; the earthworm biomass and the vermicompost [4]. Vermicomposting is a simple biotechnological process of composting in which certain species of earthworms are used to convert wastes into better end product $[5,6]$. Vermicomposting is a nonthermophilic biodegradation of organic material through the joint action of earthworms and microorganisms [3] Yadav and Garg [7] reported that earthworms act as mechanical blenders, and, by comminuting the organic matter, they modify its biological, physical, and chemical status, gradually reducing its $\mathrm{C}: \mathrm{N}$ ratio, increasing the surface area exposed to microorganisms, and making it much more favourable for microbial activity and further decomposition. It differs from composting in several ways [8]. The vermicomposting process is faster than composting, because the material passes through the earthworm gut. The resulting earthworm castings (worm manure) are rich in microbial activity and plant growth regulators and fortified with pest repellence attributes as well [6]. Earthworms consume various organic wastes and reduce the volume by $40-60 \%$ [5]. The average body weight of earthworms is $0.5-0.6 \mathrm{~g}$, and they eat wastes equivalent to their body weight. It produces cast equivalent to about $50 \%$ of the waste it consumes in a day. Vermicompost contains a higher percentage of macro- and micronutrients than ordinary compost [9]. It contains $9.8-13.4 \%$ organic carbon, $0.51-1.61 \%$ nitrogen, $0.19-1.02 \%$ phosphorus, and $0.15-0.73 \%$ potassium. The nutrients present in the vermicompost are in water soluble forms which are immediately available for plant use $[3,10]$. 
Vermicomposting reduces the $\mathrm{C}: \mathrm{N}$ ratio and retains more $\mathrm{N}$ than the traditional methods of preparing composts [8]. The $\mathrm{C}: \mathrm{N}$ ratio of unprocessed olive cake and vermicomposted olive cake was 42 and 29, respectively [5]. Vermicomposting organic materials directly affect the growth and development of earthworms [6, 11]. Nogales et al. [12] reported that larger weights of newly hatched earthworms were obtained in substrate containing dry oil cake. In another study, maize straw was found to be the most suitable feed material compared to soybean straw, wheat straw, chickpea straw, and city refuse [13]. Zajonc and Sidor [14] studied mixtures of cotton waste with cattle manure and found the ratio of $1: 5$ to be the best.

Tropical root and tuber crops produce the highest dry matter per unit area per unit time. Sweet potato and cassava produce edible energy of 194 and $138 \mathrm{MJ} /$ ha/day [15]. Further, they are more efficient in conversion of biological yield into economic yield $[16,17]$. Cassava and sweet potato are the most important root crops in the world [18]. The starchy roots of these crops are consumed directly after boiling or baking. The roots are also used as a major source of raw material for starch industries in tropical and subtropical countries. The byproduct (waste) of the starch industry is called "thippi." Cassava and sweet potato produce large quantity of biomass yield [19]. The leaves and immature stems/vines of these crops are good sources of organic matter and nutrients. At present, the vegetative parts of these crops are either ploughed back or burned. Byproducts of these root crops can be efficiently used for enriching the soil fertility. Earthworms are able to convert these byproducts (wastes) into nutrient rich vermicompost. Keeping in view of the above, the present investigation was carried out to explore the possibilities of converting byproducts/wastes of cassava and sweet potato into quality vermicompost. The study also attempted to ascertain the variability in nutrient content, microbial diversity, and duration of vermicomposting by different byproducts.

\section{Materials and Methods}

A pot culture experiment on vermicomposting of biomass and byproducts of cassava and sweet potato was conducted for March-May (season I) and June-August (season II) during 2010 at the Regional Centre of Central Tuber Crops Research Institute, Bhubaneswar, Orissa. The weather during March-May was hot and dry. The maximum temperature has reached $40^{\circ} \mathrm{C}$ during May. During June-August, the weather was wet and humid. The experiment was conducted in randomized block design (RBD) with three replications. The seven treatments used in the experiment were garden fresh residues $(4 \mathrm{~kg})$, cassava fresh leaves $(4 \mathrm{~kg})$, cassava dry leaves $(1 \mathrm{~kg})$, cassava thippi $(1 \mathrm{~kg})$, sweet potato fresh leaves $(4 \mathrm{~kg})$, sweet potato dry leaves $(1 \mathrm{~kg})$, and sweet potato thippi $(1 \mathrm{~kg})$. The variation in quantity of substrate used was due to level of moisture content. Fresh leaves contain $80 \%$ water, and dry leaves/thippi contain 16-20\% water. Four kg of fresh cow dung was added uniformly in all the seven treatments. Plastic pots of $60 \mathrm{~cm}$ diameter at the top and $45 \mathrm{~cm}$ at the bottom and $60 \mathrm{~cm}$ height were used for the study. Small hole was made in the bottom of the pot to drain out excess water. The pots were kept on a plastic tray. In each plastic pot, the first layer from bottom $(3 \mathrm{~cm})$ was filled with smallsize stones for good aeration and easy drainage of water. The second layer $(3 \mathrm{~cm})$ was filled with sand for proper filtration and to work as a check gate for preventing the earthworms to move to the bottom layer. The third layer $(3 \mathrm{~cm})$ was filled with garden soil, which is for maintaining the moisture level and to act as a bedding material for the earthworms. The fourth layer $(3 \mathrm{~cm})$ was filled with well-decomposed cow dung, and, above this layer, feeding materials (crop residue and fresh cow dung) were placed as per different treatments. The crop residue was chopped into small pieces before mixing with fresh cow dung. The feeding material was subjected to aerobic composting and was placed in the plastic pots after a week when the mixture was partially decomposed. Moisture content of the compost was maintained at $60-70 \%$. The earthworm Eisenia foetida obtained from the vermicomposting unit, Central Horticultural Experimentation Station, Bhubaneswar, Orissa, was placed in the plastic pots at 20 worms per pot. The experimental plastic pots were kept under shade and covered with wet jute bags to avoid direct sunlight.

The vermicompost was harvested when all the crop residues and byproducts and organic wastes were completely turned into castings. The vermicompost and vermicompost wash samples were collected in sterile containers before harvesting the compost, and the enumeration of microbial load was done by dilution plate technique using selective media. The media used were Rose Bengal agar (fungi), King's B agar and nutrient agar (bacteria), and Ken Knights and Munaier's agar (actinomycetes). The number of colony forming units (cfu) was expressed as $\mathrm{cfu}^{-1}$. The population was analyzed for microbial diversity. The worm number and weight were recorded at the time of harvest.

The weather during March-May 2010 was hot and dry, whereas during June-August wet and humid (Table 1). The $\mathrm{pH}$, electrical conductivity (EC), organic carbon, nitrogen, phosphorus, and potassium content of the feeding materials were analyzed before subjecting to compost by following standard procedure [20], and the results are presented in the Table 2. The above chemical analyses were also carried on the vermicompost prior to harvest. Natural log transformed values of microbial populations were used for statistical analysis. The data were analyzed using Genstat statistical software. The treatment means were compared with the least significant difference (LSD) at a 5\% level of probability [21].

\section{Results}

3.1. Nutrient Content. The vermicomposts from various feeding materials recorded more or less neutral $\mathrm{pH}$ ranging from 6.32 to 6.86 (Table 3). The highest $\mathrm{pH}$ was found in garden residue vermicompost during both the seasons. The lowest $\mathrm{pH}$ was observed in sweet potato dry leaves vermicompost. In general, $\mathrm{pH}$ of the vermicompost in season I was higher than in season II. The electrical conductivity of the vermicomposts was ranged from $2.82 \mathrm{dSm}^{-1}$ to $5.38 \mathrm{dSm}^{-1}$ (Table 3 ). The highest EC was noticed in cassava 
TABLE 1: Weather during vermicomposting.

\begin{tabular}{|c|c|c|c|c|c|c|c|}
\hline \multirow{2}{*}{ Months } & \multicolumn{3}{|c|}{ Temperature $\left({ }^{\circ} \mathrm{C}\right)$} & \multicolumn{3}{|c|}{ Relative humidity (\%) } & \multirow{2}{*}{ Rainfall (mm) } \\
\hline & Maximum & Minimum & Mean & Maximum & Minimum & Mean & \\
\hline March & 37.3 & 24.3 & 30.8 & 92 & 48 & 70 & 5.4 \\
\hline April & 39.1 & 26.7 & 32.9 & 88 & 48 & 68 & 0.0 \\
\hline May & 37.0 & 26.7 & 31.8 & 87 & 61 & 74 & 203.8 \\
\hline June & 35.5 & 26.9 & 31.2 & 91 & 70 & 81 & 196.1 \\
\hline July & 33.0 & 26.2 & 29.6 & 92 & 75 & 84 & 209.2 \\
\hline August & 33.3 & 26.4 & 29.8 & 92 & 75 & 84 & 253.5 \\
\hline
\end{tabular}

TABLE 2: Initial chemical characteristics of vermicomposting materials.

\begin{tabular}{|c|c|c|c|c|c|c|c|c|c|c|c|c|}
\hline \multirow{2}{*}{ Feeding materials } & \multicolumn{2}{|c|}{$\mathrm{pH}$} & \multicolumn{2}{|c|}{$\mathrm{EC}\left(\mathrm{dSm}^{-1}\right)$} & \multicolumn{2}{|c|}{ Organic carbon (\%) } & \multicolumn{2}{|c|}{ Nitrogen (\%) } & \multicolumn{2}{|c|}{ Phosphorus (\%) } & \multicolumn{2}{|c|}{ Potassium (\%) } \\
\hline & $I^{*}$ & $\mathrm{II}^{* *}$ & I & II & $\mathrm{I}$ & II & I & II & I & II & I & II \\
\hline Cow dung & 6.79 & 6.68 & 1.12 & 1.23 & 19.75 & 20.22 & 0.46 & 0.47 & 0.12 & 0.16 & 0.43 & 0.40 \\
\hline Garden residues & 6.61 & 6.59 & 1.22 & 1.33 & 23.57 & 23.59 & 1.10 & 1.01 & 0.18 & 0.18 & 0.43 & 0.32 \\
\hline Cassava leaves & 6.59 & 6.58 & 1.14 & 1.24 & 26.66 & 25.84 & 1.12 & 1.11 & 0.23 & 0.24 & 0.32 & 0.30 \\
\hline Cassava thippi & 6.81 & 6.70 & 3.94 & 3.52 & 18.95 & 19.43 & 0.83 & 0.77 & 0.12 & 0.11 & 0.23 & 0.22 \\
\hline Sweet potato leaves & 6.53 & 6.54 & 1.29 & 1.52 & 25.96 & 26.79 & 2.06 & 1.98 & 0.35 & 0.31 & 0.52 & 0.41 \\
\hline Sweet potato thippi & 6.88 & 6.73 & 2.24 & 2.32 & 19.47 & 18.45 & 0.92 & 0.84 & 0.15 & 0.12 & 0.34 & 0.29 \\
\hline
\end{tabular}

${ }^{*}$ Season I.

** Season II.

thippi vermicompost in both the seasons. The lowest EC was observed in garden residue vermicompost. In all the vermicomposts, higher EC was observed in season I than in season II. Vermicomposting decreased the organic carbon content (38.8-43.1\%) in all the tuber crops byproducts. Garden residues vermicompost had the lowest amount of organic carbon compared to all other vermicomposts.

All the vermicomposts recorded higher levels of nutrients than the original feeding materials (Table 3). However, marked variation in nutrient content was noticed among the vermicomposts. The sweet potato dry leaves vermicompost had the highest nitrogen content in season I and II. It was followed by cassava fresh leaves. The lowest nitrogen contents of $1.25 \%$ in season I and $1.12 \%$ in season II were recorded in cassava thippi as feeding material. The vermicompost obtained from sweet potato dry leaves recorded the highest phosphorus content which was followed by the vermicompost obtained from cassava fresh leaves during both the years, whereas, the lowest phosphorus content in the vermicomposts was obtained from cassava thippi. The vermicompost made from sweet potato dry leaves recorded the highest potassium content. It was followed by cassava fresh leaves. The lowest potassium content was recorded in cassava thippi as feeding material during both seasons of study.

3.2. Duration of Vermicomposting. The number of days required for vermicomposting varied with the type of materials used (Table 4). Cassava thippi took 43 days and 40 days in season I and season II, respectively, for the complete conversion into vermicompost whereas sweet potato thippi took 45 days and 43 days in season I and season II, respectively. Other feeding materials took longer for complete conversion into vermicompost. Season II required relatively fewer days for complete vermicomposting than season I.

3.3. Earthworm Multiplication. The earthworm growth and reproduction was significantly influenced by the type of feeding materials (Table 5). The rate of increase of earthworm weight and population was higher in vermicompost made from cassava and sweet potato thippi, which was followed by sweet potato fresh leaves. The increase of the earthworm weight in season I and II was 93.8 and $120.6 \%$, respectively, when cassava thippi was used as feeding material. In the case of sweet potato thippi treatment, the increase of the earthworm weight was 71.9 and $117.6 \%$ in season I and II, respectively. The increase of the earthworm population in cassava thippi was 275 and $380 \%$ in season I and season II, respectively. Sweet potato fresh leaves as feeding material recorded 56.3 and $67.6 \%$ increase in body weight and 190 and $265 \%$ increase in population of the earthworm in season I and II, respectively. The rate of increase in weight and population of the earthworm was found to be lowest in vermicompost made from cassava fresh leaves. An increase in weight of 3.1 and $23.5 \%$ and in of population of 35 and $80 \%$ in season I and II, respectively, was recorded for this treatment.

3.4. Microbial Diversity. Microbial counts were affected by the nature of the feeding materials (Table 6). Populations of bacteria and fungi in season I were significantly higher than season II. However, actinomycete population was higher in season II. Even though, in season I, bacterial populations were highest in the garden residues and cassava dry leaves, populations in sweet potato fresh leaves and cassava thippi 
TABLE 3: Chemical characteristics of vermicompost.

\begin{tabular}{|c|c|c|c|c|c|c|c|c|c|c|c|c|}
\hline \multirow{2}{*}{ Vermicompost } & \multicolumn{2}{|c|}{$\mathrm{pH}$} & \multicolumn{2}{|c|}{$\mathrm{EC}\left(\mathrm{dSm}^{-1}\right)$} & \multicolumn{2}{|c|}{ Organic carbon $(\%)$} & \multicolumn{2}{|c|}{ Nitrogen (\%) } & \multicolumn{2}{|c|}{ Phosphorus (\%) } & \multicolumn{2}{|c|}{ Potassium (\%) } \\
\hline & $\mathrm{I}^{*}$ & $\mathrm{II}^{* *}$ & I & II & I & II & I & II & I & II & I & II \\
\hline Garden residues & 6.66 & 6.65 & 3.02 & 2.82 & 12.19 & 11.96 & 1.32 & 1.22 & 0.39 & 0.26 & 0.55 & 0.33 \\
\hline Cassava fresh leaves & 6.61 & 6.58 & 4.93 & 4.81 & 15.05 & 15.62 & 1.98 & 1.66 & 0.64 & 0.59 & 0.67 & 0.63 \\
\hline Cassava dry leaves & 6.57 & 6.54 & 3.91 & 3.82 & 15.18 & 15.82 & 1.52 & 1.59 & 0.55 & 0.54 & 0.52 & 0.60 \\
\hline Cassava thippi & 6.65 & 6.62 & 5.38 & 5.06 & 13.01 & 13.29 & 1.25 & 1.12 & 0.45 & 0.34 & 0.46 & 0.49 \\
\hline Sweet potato fresh leaves & 6.61 & 6.59 & 3.57 & 3.43 & 17.42 & 18.29 & 1.82 & 1.57 & 0.61 & 0.58 & 0.59 & 0.55 \\
\hline Sweet potato dry leaves & 6.32 & 6.34 & 4.80 & 4.76 & 13.64 & 14.21 & 2.23 & 2.03 & 0.88 & 0.69 & 1.29 & 0.84 \\
\hline Sweet potato thippi & 6.69 & 6.62 & 3.64 & 3.50 & 12.19 & 11.96 & 1.46 & 1.21 & 0.49 & 0.38 & 0.53 & 0.42 \\
\hline $\operatorname{LSD}(P=0.05)$ & 0.08 & 0.10 & 0.12 & 0.15 & 1.32 & 1.22 & 0.08 & 0.08 & 0.01 & 0.02 & 0.01 & 0.18 \\
\hline
\end{tabular}

* Season I.

** Season II.

TABLE 4: Time taken for complete conversion of composting materials into fully matured vermicompost.

\begin{tabular}{lcc}
\hline \multirow{2}{*}{ Vermicompost } & \multicolumn{2}{c}{ Time (days) } \\
& Season I & Season II \\
\hline Garden residues & 49 & 48 \\
Cassava fresh leaves & 65 & 60 \\
Cassava dry leaves & 60 & 58 \\
Cassava thippi & 43 & 40 \\
Sweet potato fresh leaves & 62 & 58 \\
Sweet potato dry leaves & 59 & 54 \\
Sweet potato thippi & 45 & 43 \\
LSD $(P=0.05)$ & 7 & 5 \\
\hline
\end{tabular}

remained constant during both the seasons. The highest bacterial population was found in garden residue, and it was at par with cassava dry leaves. The maximum fungal populations were observed with cassava dry leaves and cassava thippi, whereas the highest actinomycete population was observed in cassava fresh leaves.

\section{Discussion}

The vermicomposts from various feeding materials had more or less neutral $\mathrm{pH}$, and it was less than the initial value (Tables 2 and 3 ). The lower $\mathrm{pH}$ recorded in the final products might have been due to the production of $\mathrm{CO}_{2}$, ammonia, $\mathrm{NO}_{3}{ }^{-}$, and organic acids by microbial metabolism during decomposition of different substrates in the feed mixtures $[2,3,22]$. However, the observed difference in reduction of $\mathrm{pH}$ among vermibeds could be attributed to the nature of organic waste, which affects the mineralization process and species of intermediate compounds in vermireactors. Increase in electrical conductivity of the vermicompost irrespective of kind of feed substrate was noticed (Tables 2 and 3). This may be attributed due to freely available ions and minerals that are generated during ingestion and excretion by the earthworms. Vermicomposting decreased the organic carbon content in the tuber crops byproducts. The maximum reduction in organic carbon $(38.8-43.1 \%)$ was obtained in cassava dry leaves vermicompost in comparison to other wastes/byproducts. Elvira et al. [23], Kaushik and Garg [24], Garg et al. [2], and Sen and Chandra [4] also observed a $20-52 \%$ loss of carbon as $\mathrm{CO}_{2}$ during vermicomposting.

All the vermicomposts of different agroindustrial wastes recorded higher levels of nutrients (nitrogen, phosphorus, and potassium) than the original feeding materials. Gunadi and Edwards [25] also demonstrated that nutrient content in the end product of vermicomposting was high. The increase of nitrogen content of the compost was probably due to mineralization of organic matter (Tables 2 and 3). Loss of organic carbon might be also responsible for nitrogen enhancement. Decrease in $\mathrm{pH}$ may be an important factor in nitrogen retention as this element is lost as volatile ammonia at higher $\mathrm{pH}$ (Tables 2 and 3). Increase in nitrogen content in the final product in the form of mucus, nitrogenous excretory substances, growth stimulating hormones, and enzymes from earthworms has also been reported [26]. Earthworms also have a great impact on nitrogen transformations in manure by enhancing nitrogen mineralization so that mineral nitrogen may be retained in the nitrate form [27]. However, in general, final nitrogen content of the vermicompost is dependent on the initial nitrogen present in the byproducts [2]. Total phosphorus content in all the vermicomposts was higher than the initial feed substrate (Tables 2 and 3). Garg et al. [2] observed that plant litter was found to contain more available $\mathrm{P}$ after ingestion by earthworms, which may be due to the physical breakdown of the plant material by worms. Increase in phosphorus in vermicompost is probably due to mineralization and mobilization of phosphorus as a result of bacterial and faecal phosphatase activity of earthworms [2]. Potassium was also higher in the final vermicompost than in the initial feed substrates. It indicated that the microbial flora also influences the level of available potassium. Acid production by the microorganisms seems to be a prime mechanism for solubilizing the insoluble potassium.

The number of days required for vermicomposting varied with the type of substrate used and season of vermicomposting (Table 4). Fresh leaves of cassava and sweet potato needed more time to decompose compared to dried leaves 
TABLE 5: Earthworm growth and development in various vermicompost.

\begin{tabular}{|c|c|c|c|c|c|c|c|c|}
\hline \multirow{3}{*}{ Vermicompost } & \multicolumn{4}{|c|}{ Season I } & \multicolumn{4}{|c|}{ Season II } \\
\hline & & Initial & & Final & & Initial & & Final \\
\hline & Number & $\begin{array}{l}\text { Average weight } \\
(\mathrm{g})\end{array}$ & Number & $\begin{array}{l}\text { Average weight } \\
(\mathrm{g})\end{array}$ & Number & $\begin{array}{l}\text { Average weight } \\
(\mathrm{g})\end{array}$ & Number & $\begin{array}{l}\text { Average weight } \\
(\mathrm{g})\end{array}$ \\
\hline Garden residues & 20 & 3.2 & 52 & 3.7 & 20 & 3.4 & 63 & 6.1 \\
\hline Cassava fresh leaves & 20 & 3.2 & 27 & 3.3 & 20 & 3.4 & 36 & 4.2 \\
\hline Cassava dry leaves & 20 & 3.2 & 45 & 3.4 & 20 & 3.4 & 61 & 5.2 \\
\hline Cassava thippi & 20 & 3.2 & 75 & 6.2 & 20 & 3.4 & 96 & 7.5 \\
\hline $\begin{array}{l}\text { Sweet potato fresh } \\
\text { leaves }\end{array}$ & 20 & 3.2 & 58 & 5.0 & 20 & 3.4 & 73 & 5.7 \\
\hline $\begin{array}{l}\text { Sweet potato dry } \\
\text { leaves }\end{array}$ & 20 & 3.2 & 43 & 4.7 & 20 & 3.4 & 52 & 5.6 \\
\hline Sweet potato thippi & 20 & 3.2 & 78 & 5.5 & 20 & 3.4 & 92 & 7.4 \\
\hline $\operatorname{LSD}(P=0.05)$ & 一 & 一 & 6 & 0.2 & 一 & 一 & 9 & 0.4 \\
\hline
\end{tabular}

TABLE 6: Microbial population in various vermicompost.

\begin{tabular}{|c|c|c|c|c|c|c|}
\hline \multirow{2}{*}{ Vermicompost } & \multicolumn{2}{|c|}{ Bacteria $\times 10^{6}$} & \multicolumn{2}{|c|}{ Fungi $\times 10^{4}$} & \multicolumn{2}{|c|}{ Actinomycetes $\times 10^{4}$} \\
\hline & Season I & Season II & Season I & Season II & Season I & Season II \\
\hline Garden residues & $172.6(18.96)$ & $52.0(17.76)$ & $23.0(16.93)$ & $12.6(16.28)$ & $27.6(17.13)$ & $92.0(18.33)$ \\
\hline Cassava fresh leaves & $20.3(16.77)$ & $17.3(16.66)$ & $22.0(16.90)$ & $7.0(15.75)$ & $67.3(18.02)$ & $123.0(18.62)$ \\
\hline Cassava dry leaves & $172.0(18.94)$ & $33.0(17.30)$ & $35.3(17.37)$ & $11.3(16.21)$ & $38.0(17.45)$ & $155.0(18.84)$ \\
\hline Cassava thippi & $41.3(17.51)$ & $45.0(17.57)$ & $26.3(17.06)$ & $19.0(16.75)$ & $30.6(17.23)$ & $76.3(18.14)$ \\
\hline Sweet potato fresh leaves & $71.0(18.07)$ & $78.6(18.17)$ & $13.0(16.37)$ & $23.3(16.94)$ & $80.0(18.19)$ & $48.3(17.68)$ \\
\hline Sweet potato dry leaves & $11.6(16.25)$ & $47.3(17.67)$ & $19.3(16.70)$ & $19.3(16.77)$ & $77.3(18.16)$ & $71.6(18.08)$ \\
\hline Sweet potato thippi & $130.6(18.67)$ & $35.0(17.36)$ & $24.0(16.95)$ & $9.0(16.00)$ & $58.3(17.88)$ & $99.6(18.41)$ \\
\hline $\operatorname{LSD}(P=0.05)$ & 0.43 & 0.25 & 0.45 & 0.47 & 0.10 & 0.19 \\
\hline
\end{tabular}

and thippi. Wet and humid conditions favoured early maturation of compost in season II. An increase in earthworm population was found in all the feeding substrates, with varying rates (Table 5). Garg and Kaushik [9] also found similar results when they used textile mill sludge as feeding substrate along with poultry droppings. The increase in the earthworm population might be attributed to the decrease in $C: N$ ratio [28]. The rate of increase in weight and population of the earthworms was found to be lowest in vermicompost made from cassava fresh leaves. This may be due to the cyanogenic glucosides in fresh cassava leaves which were not fully eliminated during partial decomposition and that might have influenced the growth and reproduction of earthworms. Furthermore, the earthworms might not have received sufficient microbes for feeding. Quality of substrate (palatability and nutrient status) influences the fecundity of earthworms $[3,6]$. In season II, the earthworm weight and population were higher than in season I. This was due to the influence of ambient temperature and relative humidity (Table 1).

Dominguez [29] reported that vermicomposting is a combined operation of earthworm and microorganisms. The nature of the feeding substrate and season influenced the populations of microorganisms (Table 6). Suthar and Singh [30] reported that release of intermediate compounds during composting influences worm growth and reproduction and microflora composition. Hot and dry conditions during March-May (Table 1) favoured multiplication of bacteria and fungi in season I vermicomposts (Table 6). Further, the growth and development of earthworms (which feeds microbes) was reduced during the above period. Wet and humid conditions between June and August (Table 1) might have been responsible for higher earthworm and actinomycetes populations in season II vermicomposts (Table 6). But there may be a microbial equilibrium existing among various kinds of organisms which decides the ultimate population. In general, cassava supports more microbial population during vermicomposting. This might be due to the lesser number of earthworms (Table 5), which feed on microbes along with organic matter. Despite high variability in populations shown by various substrates, the array of organisms remained the same in all the substrates.

\section{Conclusion}

The biomass and byproducts of tuber crops were vermicomposted in 40-65 days. They were fairly rich in major nutrients and better in nutritional composition compared to initial levels. The nature of the feeding material determined the 
nutrient content, microbial diversity, earthworm population, and time required for complete vermicomposting. This study indicated that all biomass and byproducts of tuber crops can be effectively converted into high-value vermicompost.

\section{References}

[1] S. Bansal and K. K. Kapoor, "Vermicomposting of crop residues and cattle dung with Eisenia foetida," Bioresource Technology, vol. 73, no. 2, pp. 95-98, 2000.

[2] P. Garg, A. Gupta, and S. Satya, "Vermicomposting of different types of waste using Eisenia foetida: a comparative study," Bioresource Technology, vol. 97, no. 3, pp. 391-395, 2006.

[3] S. Suthar, "Vermicomposting of vegetable-market solid waste using Eisenia fetida: impact of bulking material on earthworm growth and decomposition rate," Ecological Engineering, vol. 35, no. 5, pp. 914-920, 2009.

[4] B. Sen and T. S. Chandra, "Chemolytic and solid-state spectroscopic evaluation of organic matter transformation during vermicomposting of sugar industry wastes," Bioresource Technology, vol. 98, no. 8, pp. 1680-1683, 2007.

[5] K. P. Nagavallemma, S. P. Wani, S. Lacroix et al., "Vermicomposting: recycling wastes into valuable organic fertilizer," in Global Theme on Agroecosystems, Report No. 8, p. 20, ICRISAT, Patancheru, Andhra Pradesh, India, 2004.

[6] V. K. Garg, S. Chand, A. Chhillar, and A. Yadav, "Growth and reproduction of Eisenia foetida in various animal wastes during vermicomposting," Applied Ecology and Environmental Research, vol. 3, no. 2, pp. 51-59, 2005.

[7] A. Yadav and V. K. Garg, "Recycling of organic wastes by employing Eisenia fetida," Bioresource Technology, vol. 102, no. 3, pp. 2874-2880, 2011.

[8] M. Gandhi, V. Sangwan, K. K. Kapoor, and N. Dilbaghi, "Composting of household wastes with and without earthworms," Eco Environments, vol. 15, no. 2, pp. 272-279, 1997.

[9] V. K. Garg and P. Kaushik, "Vermistabilization of textile mill sludge spiked with poultry droppings by an epigeic earthworm Eisenia foetida," Bioresource Technology, vol. 96, no. 9, pp. 1063-1071, 2005.

[10] P. M. Ndegwa and S. A. Thompson, "Integrating composting and vermicomposting the treatment and bioconversion of biosoilds," Bioresource Technology, vol. 76, pp. 107-112, 2001.

[11] R. P. Singh, M. H. Ibrahim, N. Esa, and M. S. Iliyana, "Composition of waste from palm oil mill: a sustainable waste management practice," Reviews in Environmental Science and Biotechnology, vol. 9, pp. 331-344, 2010.

[12] R. Nogales, R. Melgar, A. Guerrero et al., "Growth and reproduction of Eisenia andrei in dry olive cake mixed with other organic wastes," Pedobiologia, vol. 43, no. 6, pp. 744-752, 1999.

[13] M. C. Manna, M. Singh, S. Kundu, A. K. Tripathi, and P. N. Takkar, "Growth and reproduction of the vermicomposting earthworm Perionyx excavatus as influenced by food materials," Biology and Fertility of Soils, vol. 24, no. 1, pp. 129-132, 1997.

[14] I. Zajonc and V. Sidor, "Use of some wastes for vermicompost preparation and their influence on growth and reproduction of the earthworm Eisenia foetida," Polnohospodars-tvo, vol. 36, no. 8, pp. 742-752, 1990.

[15] J. A. Woolfe, Sweet Potato: An Untapped Food Resource, Cambridge University Press, Cambridge, UK, 1992.

[16] M. Nedunchezhiyan and R. C. Ray, "Sweet potato growth, development production and utilization: overview," in Sweet Potato: Post Harvest Aspects in Food, R. C. Ray and K. I.
Tomlins, Eds., pp. 1-26, Nova Science, New York, NY, USA, 2010.

[17] M. Nedunchezhiyan, "Tuber crops for sustainable rural livelihood improvement," in Enhancing Water Productivity through Integrated Water Resources Management, M. Raychaudhuri, S. K. Srivastava, and K. Ashwani, Eds., pp. 97-100, Directorate of Water Management (ICAR), Bhubaneswar, Odisha, India, 2011.

[18] S. Edison, "Scope and strategies for development of tuber crops based farming system for food security and sustainable environment," in Root and Tuber Crops: In Nutrition, Food Security and Sustainable Environment, S. K. Naskar, M. Nedunchezhiyan, K. Rajasekhara Rao et al., Eds., pp. 3-9, Regional Centre of CTCRI, ICAR, Bhubaneswar, India, 2006.

[19] C. S. Suchitra, A. C. Hridya, M. Haripriya Anand, and G. Byju, "Biomass production of contrasting cassava cultivars and their potential for food, animal feed and biofuels in India," in Proceedings of the 2nd International Seminar and Workshop on Sustainable Utilization of Tropical Plant Biomass, pp. 87-88, Thiruvananthapuram. Organised by Kerala University, Kerala and Lund University, Sweden, December 2010.

[20] AOAC, Official Methods of Analysis. Association of Official Analytical Chemists, Gathersburg, Md, USA, 2001.

[21] K. A. Gomez and A. A. S. Gomez, Statistical Procedures for Agricultural Research, John Wiley \& Sons, New York, NY, USA, 1984.

[22] S. Suthar, "Recycling of agro-industrial sludge through vermitechnology," Ecological Engineering, vol. 36, no. 8, pp. 10281036, 2010.

[23] C. Elvira, L. Sampedro, E. Benítez, and R. Nogales, "Vermicomposting of sludges from paper mill and dairy industries with Eisena andrei: a pilot-scale study," Bioresource Technology, vol. 63, no. 3, pp. 205-211, 1998.

[24] P. Kaushik and V. K. Garg, "Vermicomposting of mixed solid textile mill sludge and cow dung with the epigeic earthworm Eisenia foetida," Bioresource Technology, vol. 90, no. 3, pp. 311316, 2003.

[25] B. Gunadi and C. A. Edwards, "The effects of multiple applications of different organic wastes on the growth, fecundity and survival of Eisenia fetida (Savigny) (Lumbricidae)," Pedobiologia, vol. 47, no. 4, pp. 321-329, 2003.

[26] G. Tripathi and P. Bhardwaj, "Comparative studies on biomass production, life cycles and composting efficiency of Eisenia fetida (Savigny) and Lampito mauritii (Kinberg)," Bioresource Technology, vol. 92, no. 3, pp. 275-283, 2004.

[27] R. M. Atiyeh, J. Dominguez, S. Subler, and C. A. Edwards, "Changes in biochemical properties of cow manure during processing by earthworms (Eisenia andrei, Bouche) and the effects on seedling growth," Pedobiologia, vol. 44, no. 6, pp. 709-724, 2000.

[28] P. M. Ndegwa, S. A. Thompson, and K. C. Das, "Effects of stocking density and feeding rate on vermicomposting of biosolids," Bioresource Technology, vol. 71, no. 1, pp. 5-12, 2000.

[29] J. Dominguez, "State of the art and new perspectives on vermicomposting research," in Earthworm Ecology, C. A. Edwards, Ed., pp. 401-424, CRC Press, 2nd edition, 2004.

[30] S. Suthar and S. Singh, "Feasibility of vermicomposting in biostabilization of sludge from a distillery industry," Science of the Total Environment, vol. 394, no. 2-3, pp. 237-243, 2008. 

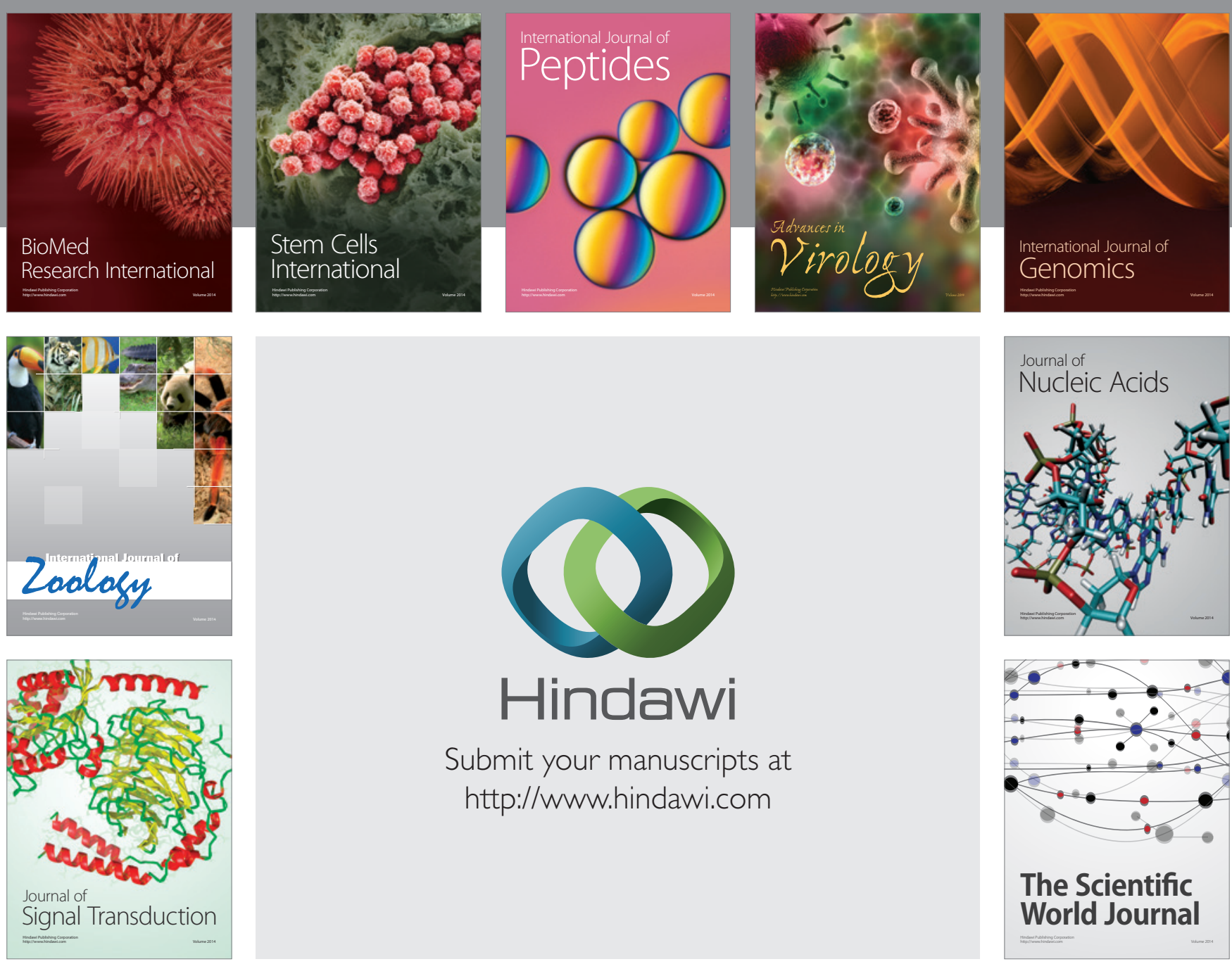

Submit your manuscripts at

http://www.hindawi.com
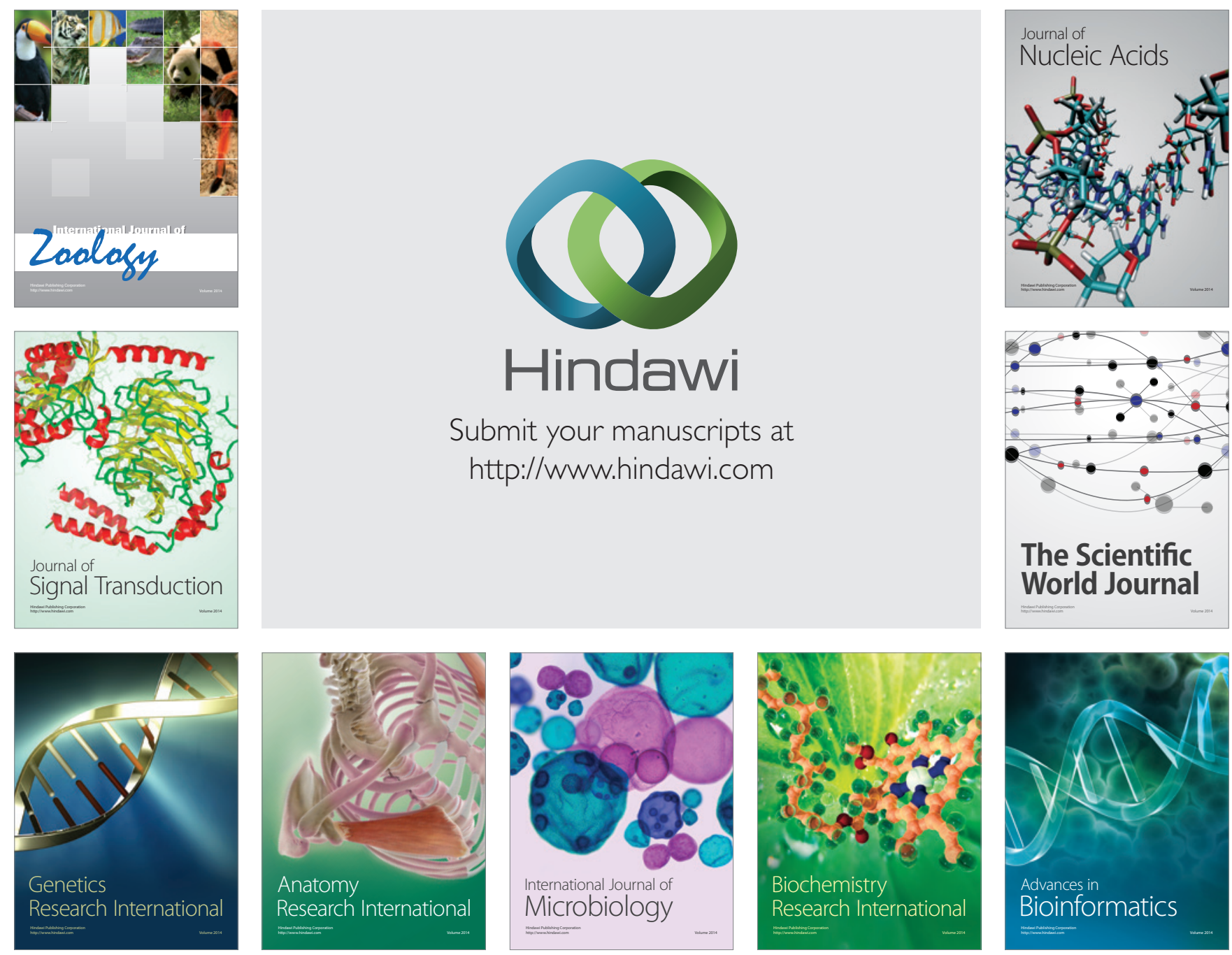

The Scientific World Journal
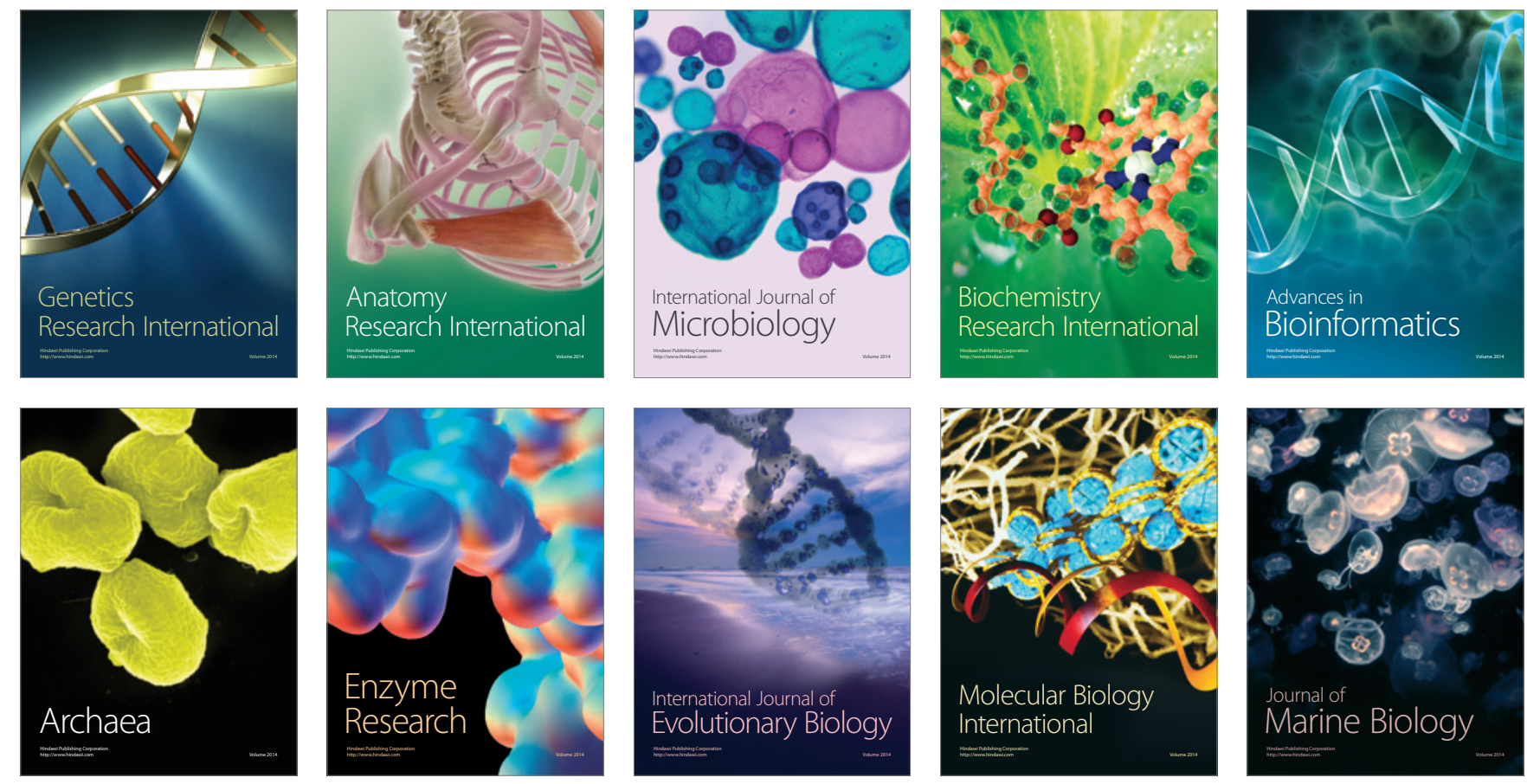